\title{
PENERAPAN MODEL PEMBELAJARAN BERBASIS MASALAH \\ (PBM) UNTUK MENINGKATKAN HASIL BELAJAR IPA SISWA DI KELAS V SD NEGERI PASURUHAN PATI
}

\author{
Nanik Istika Wati*, Sri Utaminingsih, Fina Fakhriyah \\ *) Dosen Progdi PGSD, FKIP, Universitas Muria Kudus \\ e-mail: mrs.nanik.istika@gmail.com; Hp: +6289653780730
}

\begin{abstract}
The less of teacher's skill in using inovatif learning models also delivering learning materials not related with problem in surounding make the students not enthusias in following learning process that given by the teacher can caused the student's leraning result is low. That is proved by the fact which is found in SD Negeri Pasuruhan Pati. The student's outcome is still low. From 18 students who got standard score (70) is only 5 students $(27,8 \%)$ Although 13 students $(72,2 \%)$ don't reach the standart score yet. In Result of this research, there is improvement of clasical (kognitif) standard criteria on the material of the hidrologi between previous condition $(27,8 \%)$, cycle I $(66,7 \%)$, and cycle $2(83,3 \%)$. The improvement outcome also is supported by learning management by using PBL model has improvement from average score cycle I 79,1\% (good) become $89,5 \%$ (very good) at cycle II. Although outcomes(afektif and psikomotor) also has improvement average score cycle I 77\% (good) become $88,25 \%$ (very good) at cycle II.
\end{abstract}

Key Words: Problem Based Learning (PBL) Model, Science Learning Achievement

\section{ABSTRAK}

Kurangnya keterampilan guru dalam menggunakan model-model pembelajaran yang inovatif serta penyampaian materi pembelajaran tidak dikaitkan dengan permasalahan di lingkungan sekitar membuat siswa kurang antusias dalam mengikuti proses pembelajaran yang diberikan guru dapat menyebabkan rendahnya hasil belajar siswa. Hal ini dibuktikan dengan kenyataan yang ditemui di SD Negeri Pasuruhan Pati. Hasil belajar siswa masih rendah. Dari 18 siswa yang mencapai KKM (70) hanya 5 siswa $(27,8 \%)$ sedangkan 13 siswa $(72,2 \%)$ belum mencapai KKM. Hasil penelitian terdapat peningkatan ketuntasan belajar klasikal (kognitif) pada materi daur air yang cukup signifikan antara kondisi awal $(27,8 \%)$, siklus I $(66,7 \%)$, dan siklus II $(83,3 \%)$. Peningkatan hasil belajar juga didukung dengan peningkatan pengelolaan pembelajaran guru melalui penerapan model PBM mengalami peningkatan dari skor rata-rata siklus I 79,1\% (baik) menjadi 89,5\% (sangat baik) pada siklus II. Sedangkan hasil belajar (afektif dan psikomotor) juga mengalami peningkatan skor rata-rata siklus I $77 \%$ (baik) menjadi 88,25\% (sangat baik) pada siklus II.

Kata Kunci: Model Pembelajaran Berbasis Masalah (PBM), Hasil Belajar IPA

\section{PENDAHULUAN}

Kondisi awal pembelajaran di kelas $\mathrm{V}$ SD Negeri Pasuruhan mata pelajaran IPA menunjukkan bahwa guru kurang terampil dalam mengaitkan materi pembelajaran dengan permasalahan di lingkungan sekitar siswa, guru belum menggunakan media pembelajaran yang mampu meningkatkan minat dan motivasi belajar siswa, serta guru tidak menggunakan model pembelajaran yang inovatif, yang mampu melibatkan siswa untuk berkontribusi aktif dalam proses pembelajaran. Sehingga, kondisi ini mengakibatkan rendahnya hasil belajar IPA siswa. Dalam hal ini maka diperlukan upaya pemecahan masalah dalam pembelajaran IPA siswa di kelas V SD Negeri Pasuruhan. Upaya yang dapat dilakukan dalam pemecahan masalah tersebut yaitu dengan menggunakan model pembelajaran yang dapat meningkatkan hasil belajar IPA siswa yaitu model Pembelajaran Berbasis Masalah (PBM).

Model Pembelajaran Berbasis Masalah (PBM) digunakan karena model pembelajaran ini merupakan suatu pendekatan pengajaran yang menggunakan masalah dunia nyata sebagai suatu konteks bagi siswa untuk belajar tentang cara berpikir kritis dan keterampilan pemecahan masalah, serta untuk memperoleh pengetahuan 
dan konsep yang esensial dari materi pelajaran (Nurhadi, dkk., 2004: 56-57). Model PBM tidak dapat dilaksanakan tanpa guru mengembangkan lingkungan kelas yang memungkinkan terjadinya pertukaran ide secara terbuka antara guru dengan siswa maupun siswa dengan siswa. Maka guru harus mampu menyajikan masalah untuk menarik minat belajar siswa, mengajukan pertanyaan kepada siswa, serta membimbing siswa dalam memecahkan suatu permasalahan yang dihadapi dalam proses pembelajaran. Dengan cara ini maka pertukaran informasi akan terjadi dengan lebih baik.
Belajar tergantung pada pengalaman, sebagian dari pengalaman itu merupakan umpan balik dari lingkungan sekitar. Belajar berlangsung karena usaha sadar dan sengaja untuk memperoleh informasi baru dan membawa perbaikan pada aspek kogntif, afektif, dan psikomotorik Bloom dalam (Suprijono, 2012: 6). Materi pembelajaran yang dilaksanakan pada penelitian ini yaitu daur air.

Agar penerapan model PBM terlaksana dengan baik maka pemahaman akan sintaks model ini perlu diketahui. Menurut Rusman (2012: 243) sintaks model PBM ada 5 langkah dapat dilihat tabel 1 berikut ini:

Tabel 1: Sintaks Pembelajaran Berbasis Masalah (PBM)

\begin{tabular}{|l|l|l|}
\hline No. & \multicolumn{1}{|c|}{ Tahap } & \multicolumn{1}{c|}{ Tingkah Laku Guru } \\
\hline 1. & $\begin{array}{l}\text { Tahap 1 } \\
\text { Orientasi siswa pada } \\
\text { masalah }\end{array}$ & $\begin{array}{l}\text { Menjelaskan tujuan pembelajaran, menjelaskan } \\
\text { logistik yang diperlukan, dan memotivasi siswa } \\
\text { terlibat pada aktivitas pemecahan masalah. }\end{array}$ \\
\hline 2. & $\begin{array}{l}\text { Tahap 2 } \\
\text { Mengorganisasi siswa } \\
\text { untuk belajar }\end{array}$ & $\begin{array}{l}\text { Membantu siswa untuk mendefinisikan dan } \\
\text { mengorganisasikan tugas belajar yang berhubungan } \\
\text { dengan masalah tersebut. }\end{array}$ \\
\hline 3. & $\begin{array}{l}\text { Tahap 3 } \\
\text { Membimbing } \\
\text { penyelidikan individua/ } \\
\text { kelompok. }\end{array}$ & $\begin{array}{l}\text { Mendorong siswa untuk mengumpulkan informasi } \\
\text { yang sesuai, melaksanakan eksperimen, untuk } \\
\text { mendapatkan penjelasan dan pemecahan masalah. }\end{array}$ \\
\hline 4. & $\begin{array}{l}\text { Tahap 4 } \\
\text { Mengembangkan dan } \\
\text { menyajikan hasil karya. }\end{array}$ & $\begin{array}{l}\text { Membantu siswa dalam merencanakan dan } \\
\text { menyiapkan karya yang sesuai seperti laporan, dan } \\
\text { membantu mereka untuk berbagi tugas dengan } \\
\text { temannya. }\end{array}$ \\
\hline 5. & $\begin{array}{l}\text { Tahap 5 } \\
\text { Menganalisis dan } \\
\text { mengevaluasi proses } \\
\text { pemecahan masalah. }\end{array}$ & $\begin{array}{l}\text { Membantu siswa untuk melakukan refleksi atau } \\
\text { evaluasi terhadap penyelidikan mereka dan proses- } \\
\text { proses yang mereka gunakan. }\end{array}$ \\
\hline
\end{tabular}

Penerapan model PBM sebagian besar penelitian menunjukkan bahwa ada peningkatan hasil belajar IPA siswa setelah diterapkan pada proses pembelajaran siswa. Artikel ini melaporkan kajian peningkatan hasil belajar IPA siswa melalui penerapan model PBM di kelas V SD Negeri Pasuruhan.

\section{METODE PENELITIAN}

Rancangan penelitian ini memfokuskan kegiatan di kelas sehingga menggunakan rancangan Penelitian Tindakan Kelas (PTK). Menurut Suwandi (2011: 5) menyatakan bahwa PTK yaitu suatu penelitian yang dilakukan secara sistematis-reflektif terhadap berbagai tindakan yang dilakukan oleh guru yang sekaligus sebagai peneliti, sejak disusunnya suatu perencanaan sampai penelitian terhadap tindakan nyata di dalam kelas yang berupa kegiatan belajar- mengajar, untuk memperbaiki kondisi pembelajaran yang dilakukan. Sedangkan menurut Sukidin dkk (2010: 16) tujuan PTK adalah untuk meningkatkan kemampuan guru dalam melaksanakan tugas, memperdalam pemahaman terhadap tindakan-tindakan yang dilakukan, dan memperbaiki kondisi praktikpraktik pembelajaran yang telah dilakukan.

Berdasarkan beberapa pendapat diatas PTK adalah penelitian tindakan yang dilakukan oleh guru di kelas dengan tujuan meningkatkan dan memperbaiki mutu praktik pembelajaran guru. Dan mempunyai manfaat memperbaiki mutu pendidikan dan meningkatkan hasil belajar siswa sebagai hasil dari tindakan yang dilakukan guru dalam proses pembelajaran. Menurut Arikunto, dkk (2011: 16) dalam pelaksanaan PTK ini ada empat tahapan yaitu perencanaan, pelaksanaan tindakan, observasi, dan refleksi. 
Lokasi penelitan ini dilaksanakan di SD Negeri Pasuruhan dan subyek penelitiannya siswa kelas $\mathrm{V}$ dengan karakteristik ada siswa yang berprestasi rendah, sedang dan tinggi serta dilaksanakan dalam 2 siklus untuk setiap siklusnya melalui 4 tahapan. Ada 3 teknik pengumpulan data yang digunakan yaitu observasi, tes dan dokumentasi.

Observasi difokuskan terhadap aktivitas belajar siswa untuk mengukur aspek afektif dan psikomotorik dan tes digunakan untuk mengukur kemapuan siswa aspek kognitif setelah melakukan pembelajaran. Sedangkan dokumentasi untuk mengumpulkan bukti-bukti sebagai data bukti penelitian. Tes validitas butir soal menggunkan teknik product moment angka kasar sedangkan untuk mengukur keakuratan soal tes (reliabel) dicari melalui rumus K-R 20. Sedangkan untuk analisis data penelitian menggunakan kuantitatif dan kualitatif.

\section{HASIL DAN PEMBAHASAN}

Hasil belajar merupakan perolehan dari proses tindakan belajar siswa yang menunjukkan suatu perubahan tingkah laku atau perolehan kognitif, afektif, dan psikomotorik. Hasil penelitian yang didapat dari pelaksanaan siklus I dan siklus II dapat dinyatakan bahwa pembelajaran IPA melalui penerapan model PBM pada materi daur air dapat meningkatkan hasil belajar siswa di kelas V SD Negeri Pasuruhan, baik kemampuan aspek kognitif, afektif dan psikomotorik.

Peneliti menggunakan tes akhir siklus sebagai alat untuk mengukur peningkatan hasil belajar siswa pada aspek kognitif. Lembar aktivitas belajar siswa yang digunakan untuk mengetahui letak peningkatan hasil belajar siswa aspek afektif dan psikomotorik. Sedangkan lembar pengamatan guru dalam pengelolaan pembelajaran digunakan untuk mengetahui letak peningkatan kualitas pembelajaran yang telah dilakukan melalui penerapan model Pembelajaran Berbasis Masalah (PBM) pada mata pelajaran IPA.

Berdasarkan penelitian yang telah dilakukan maka diperoleh peningkatan ketuntasan belajar klasikal (kognitif) pada materi daur air yang cukup signifikan antara kondisi awal, siklus I dan siklus II dapat dilihat pada diagram 1 berikut ini:

\section{Diagram I: Peningkatan Ketuntasan Belajar Kognitif Siswa}

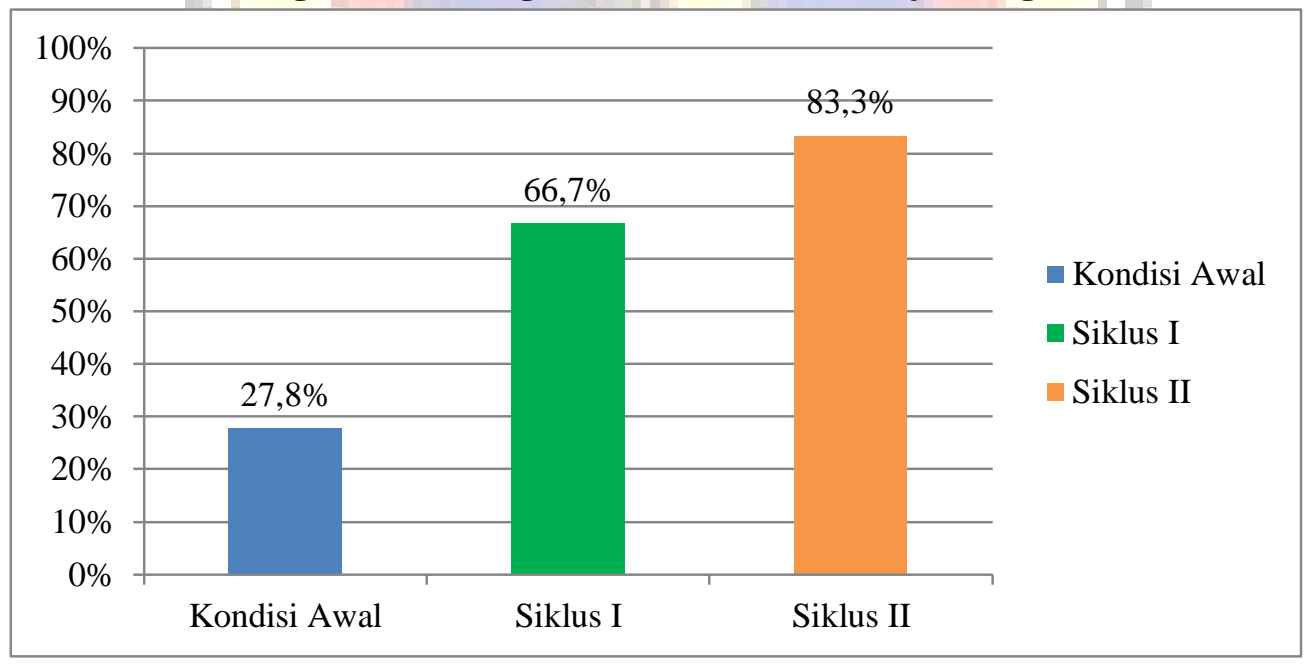

Berdasarkan diagram tersebut ada peningkatan hasil belajar klasikal siswa (kognitif) sebesar 38,9\% dari kondisi awal ke siklus I dan $16.6 \%$ dari siklus I ke siklus II. Hal ini menunjukkan bahwa siswa senang dalam melakukan penyelidikan untuk menyelesaikan permasalahan karena model PBM ini menekankan pada proses penyelidikan siswa dan siswa mengalami sendiri konsep penemuan serta penyelesaian permasalahan sehingga siswa akan lebih paham materi yang dipelajarinya sehingga hal ini berdampak pada hasil belajar siswa yang meningkat.

Sedangkan hasil belajar (afektif dan psikomotor) juga mengalami peningkatan skor rata-rata dengan kriteria baik pada siklus I dan kriteria sangat baik pada siklus II data dapat dilihat pada diagram 2 berikut ini: 


\section{Diagram 2: Peningkatan Aktivitas Belajar Siswa Aspek Afektif dan Psikomotorik}

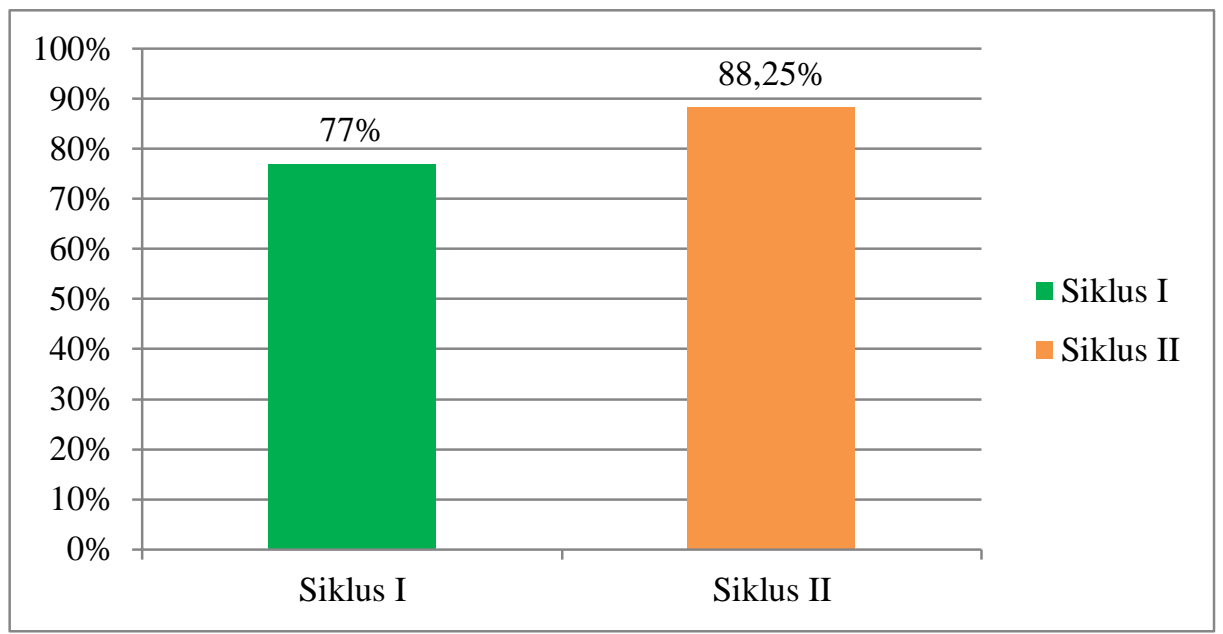

Berdasarkan data pada diagram 2
tersebut ada peningkatan sebesar $11,25 \%$ dari siklus I ke siklus II hal ini menunjukkan bahwa penerapan model PBM dapat meningkatkan hasil belajar siswa aspek afektif dan psikomotorik karena siswa senang dan semangat dalam mengikuti proses pembelajaran dibuktikan dengan antusias siswa yang tinggi dalam

mengikuti proses pembelajaran yang diberikan guru.

Peningkatan hasil belajar siswa juga didukung dengan peningkatan keterampilan pengelolaan pembelajaran guru melalui penerapan model PBM dari siklus I dengan kriteria baik menjadi sangat baik pada siklus II data dapat dilihat pada diagram 3 berikut ini:

\section{Diagram 3: Peningkatan Keterampilan Guru}

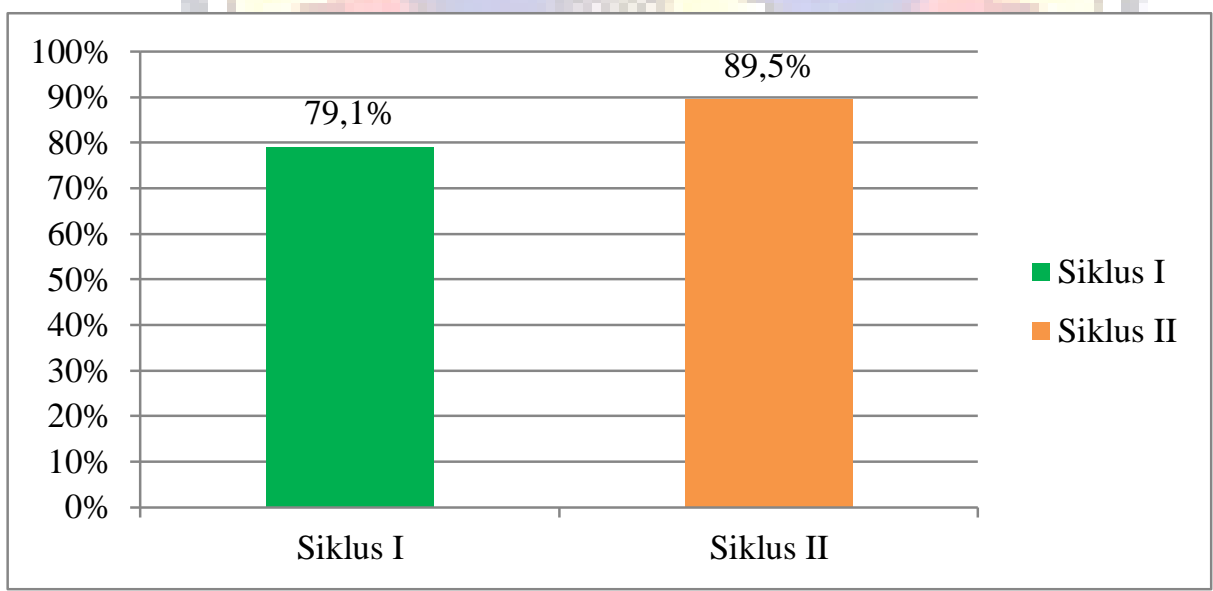

Dalam pelaksanaan tindakan pada siklus I ada beberapa kekurangan yang perlu dilakukan refleksi oleh guru agar pelaksanakan tindakan pada siklus II lebih berhasil. Pada siklus I guru belum mampu menyampaikan tujuan dan contoh permasalahan nyata yang baik, guru belum memberikan pembelajaran yang menyenangkan bagi siswa, serta dalam membimbing siswa dalam menyimpulkan masih kurang. Berdasarkan kekurangan tersebut maka diadakan perbaikan pada siklus berikutnya sehingga perbaikan dalam proses pembelajaran pada siklus II menunjukkan adanya perubahan yang signifikan. Hasil pelaksanaan pembelajaran siklus I dan siklus II menunjukkan adanya peningkatan terhadap keterampilan guru dalam pengelolaan pembelajaran melalui penerapan model PBM yaitu terdapat peningkatan sebesar $10,4 \%$ dari siklus I ke siklus II.

Berdasarkan hasil Penelitian Tindakan Kelas (PTK) yang telah dilakukan dapat disimpulkan bahwa penerapan model Pembelajaran Berbasis Masalah (PBM) dapat meningkatkan hasil belajar IPA siswa di kelas V SD Negeri Pasuruhan Pati tahun ajaran 2013/ 2014 semester II pada materi daur air. 


\section{SIMPULAN DAN SARAN}

\section{Simpulan}

Berdasarkan hasil pembahasan penelitian tindakan kelas yang telah dilaksanakan, maka diperoleh simpulan bahwa melalui penerapan model Pembelajaran Berbasis Masalah (PBM) dapat meningkatkan hasil belajar IPA siswa materi daur air di kelas V SD Negeri Pasuruhan Pati. Hal ini dibuktikan bahwa telah terjadi peningkatan keterampilan guru dalam pengelolaan pembelajaran, hasil belajar aspek kognitif, afektif dan psikomotorik. Skor keterampilan guru dalam pengelolaan pembelajaran pada siklus I adalah $79,1 \%$ meningkat menjadi $89,5 \%$ pada siklus II dari kriteria baik menjadi sangat baik.

Peningkatan hasil belajar aspek kognitif dilihat dari peningkatan nilai rata-rata kelas pada siklus I ke siklus II yaitu dari 70 menjadi 81,1 dan ketuntasan belajar siswa $66,7 \%$ menjadi $83,3 \%$. Peningkatan hasil belajar afektif dan psikomotorik dilihat dari peningkatan hasil belajar siswa (afektif dan psikomotorik) melalui lembar aktivitas siswa pada siklus I ke siklus II yaitu dari skor $77 \%$ menjadi $88,25 \%$ dengan kriteria baik menjadi sangat baik.

2. Saran

a. Guru

Guru hendaknya menerapkan model Pembelajaran Berbasis Masalah (PBM) pada mata pelajaran IPA dengan berbantuan media video pembelajaran yang berkaitan dengan materi permasalahan di sekitar lingkungan siswa.

b. Siswa

Siswa hendaknya lebih aktif dalam pembelajaran melalui penerapan model Pembelajaran Berbasis Masalah (PBM) sehingga proses belajar mengajar berpusat pada siswa.

c. Sekolah

Hendaknya sekolah memberikan kebebasan guru dalam mengembangkan modelmodel pembelajaran yang inovatif.

\section{DAFTAR PUSTAKA}

Aqib, Zainal. 2010. Profesionalisme Guru dalam Pembelajaran. Surabaya: Insan Cindekia.

${ }_{2}$ dkk. 2011. Penelitian Tindakan Kelas. Bandung: Yrama Widya.

Arikunto, Suharsimi. 2007. Dasar-dasar Evaluasi Pendidikan. Jakarta: Bumi Aksara.

2011. Penelitian Tindakan Kelas. Jakarta: Bumi Aksara.

Asdak, Chay. 2004. Hidrologi dan Pengelolaan Daerah Aliran Sungai. Yogyakarta: Gadjah Mada University Press.

BNSP. 2006. Panduan Penyusunan Kurikulum Tingkat Satuan Pendidikan JenjangPendidikan Dasar dan Menengah. Jakarta: Badan Standar Nasional Pendidikan.

Fardianz, Srikandi. 2004. Polusi Air dan Udara. Yogyakarta: Kanisius.

Kodoatie, Robert dan Sjarief, Roestam. 2008. Pengelolaan Sumber Daya Air Terpadu. Yogyakarta: Andi Offset.

Kusuma, Mohtar. 2010. Evaluasi Pendidikan. Yogyakarta: PT. Multi Kreasi Satudelapan.

Nuh, Muhammad. 2014. Implementasi Kurikulum 2013. Jakarta: Kementerian Pendidikan dan Kebudayaan.

Nurhadi, dkk. 2004. Pembelajaran Kontekstual dan Penerapannya dalam KBK. Malang: Universitas Negeri Malang.

Nurwulan, Ira. 2008. Alam dan Ekologi. Jawa Tengah: CV. Sahabat. 
Pangestuningsih, Dwi. 2013. Penerapan Model Pembelajaran Berbasis Masalah sebagai Upaya Meningkatkan Aktivitas dan Hasil Belajar Siswa pada Mata Pelajaran IPA Kelas IV SDN Balas Klumprik I/434 Surabaya. JPGSD, 02 (01), Hlm 1-6. Tersedia di http://ejournal.unesa.ac.id/index.php/jurnal-penelitian-pgsd/article/view/2954/baca-artikel.

Diunduh Tanggal 1 November 2013.

Perwita, Isa Bella Mustika. 2013. Penerapan Model Pembelajaran Berdasarkan Masalah untuk Meningkatkan Hasil Belajar IPA untuk Siswa Sekolah Dasar. JPGSD, 02 (01), Hlm: 1-8. Tersedia di http://ejournal.unesa.ac.id/index.php/jurnalpenelitianpgsd/article/view/3066/bacaartikel. Diunduh Tanggal 17 Oktober 2013.

Poerwanti, Endang., dkk. 2008. Assesment Pembelajaran SD. Jakarta: Direktorat Jendral Pendidikan Tinggi Departemen Pendidikan Nasional.

Prasetyoningsih, Desi Dwi. 2013. Penerapan Model Pembelajaran Berdasarkan Masalah untuk Meningkatkan Kemampuan Pemecahan Masalah Siswa pada Mata Pelajaran IPA SD. JPGSD, 02 (01), Hlm. $1-14 . \quad$ Tersedia di http://ejournal.unesa.ac.id/index.php/jurnalpenelitianpgsd/article/view/2949/baca-artikel.

Diunduh Tanggal 17 Oktober 2013.

Purwanto. 2013. Evaluasi Hasil Belajar. Yogyakarta: Pustaka Belajar.

Rahayu, Imam. 2009. Cara Mengatasi Air Kotor Menjadi Air Bersih. Bandung: CV Citra Praya.

Rahmawati, Herlina. 2009. Mengenal Lingkungan Sekitar Kita. Jakarta: Nobel Edumedia.

Ramadhani, Zaki. 2010. Seri IPA dan Teknologi Air. Bandung: CV Media Komunikasi.

Rasyid, Harun dan Mansur. 2009. Penilaian Hasil Belajar. Bandung: CV Wacana Prima.

Rusman. 2012. Model-model Pembelajaran. Jakarta: PT. Raja Grafindo Persada.

Rusmono. 2012. Strategi Pembelajaran dengan Problem Based Learning itu Perlu. Bogor: Ghalia Indonesia.

Slameto. 2011. Penelitian dan Inovasi Pendidikan. Salatiga: Widya Sari.

Solihin, Muh Nur El Ibrahim. 2010. Kurikulum Pembelajaran. Jakarta: Trans Mandiri Abadi.

Sugiyono. 2006. Metode Penelitian Pendidikan Pendekatan Kuantitatif, Kualitatif, dan R\&D. Bandung: Alfabeta.

Sukidin., dkk. 2010. Manajemen Penelitian Tindakan Kelas. Surabaya: Insan Cindekia.

Sukmadinata, Nana Syaodih. 2010. Metode Peneltian Tindakan. Bandung: PT. Remaja Rosdakarya.

Sumiati, dan Asra. 2009. Metode Pembelajaran. CV Wacana Prima: Bandung.

Suprijono, Agus. 2012. Cooperative Learning Teori dan Aplikasi PAIKEM. Yogyakarta: Pustaka Pelajar.

Suripin. 2004. Sistem Drainase Perkotaan yang Berkelanjutan. Yogyakarta: Andi Offset.

Suwandi, Joko. 2011. Penelitian Tindakan Kelas. Surakarta: Qinant. 
Suwandi, Sarwiji. 2011. Penelitian Tindakan Kelas (PTK) \& Penulisan Karya Ilmiah. Surakarta: Yuma Pustaka.

Trianto. 2011. Mendesain Model Pembelajaran Inovatif-Progresif. Jakarta: Prenada Media Group. . 2011. Model-model Pembelajaran Inovatif Berorientasi Konstruktivistik. Jakarta: Prestasi Pustaka.

Ulfa, Maria. 2010. Penerapan Keterampilan Proses dalam Pembelajaran IPA di Sekolah Dasar. Surabaya: CV. Duta Graha Pustaka.

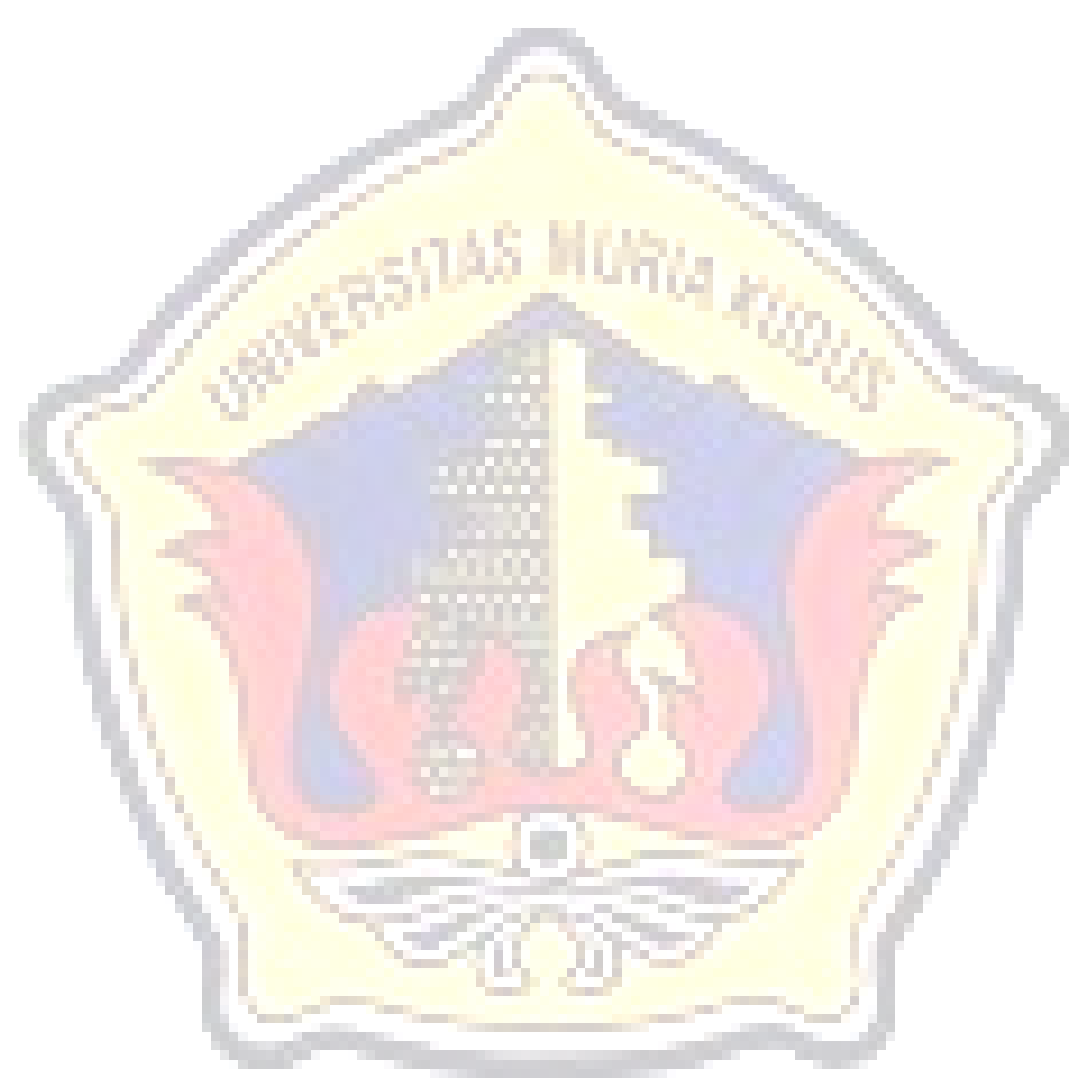

